\title{
Pemberdayaan Masyarakat dalam Pelestraian Hutan dan Pertanian Berkelanjutan di Sekitar Suaka Margasatwa Karakelang, Sulawesi Utara
}

\section{Community Empowerment on Forest Protection and Sustainable Agriculture in Villages Near Karakelang Wildlife Sanctuary, North Sulawesi}

Adi Widyanto ${ }^{\mathrm{a}}$, Sri Mulatsih ${ }^{\mathrm{b}}$, Lina Karlinasari ${ }^{\mathrm{c}}$

a Sekolah Pascasarjana, Institut Pertanian Bogor, Kampus IPB Dramaga Bogor 16680

${ }^{\mathrm{b}}$ Fakultas Ekonomi dan Manajemen, Institut Pertanian Bogor, Kampus IPB Dramaga Bogor 16680

${ }^{c}$ Fukultas Kehutanan, Institut Pertanian Bogor, Kampus IPB Dramaga Bogor 16680

\section{Article Info:}

Received: 26 - 09 - 2018

Accepted: 15 - 07 - 2019

Keywords:

Attitude, conservation, empowerment, knowledge, practice.

Corresponding Author: Adi Widyanto

Sekolah Pascasarjana, Institut Pertanian Bogor, Kampus IPB Dramaga Bogor 16680

Tel. +62-251-8357222, +62-

8111166478

Email: kundunku@gmail.com

\begin{abstract}
The protection of Karakelang wildlife sanctuary has been challenged by forest encroachment, timber harvesting and wildlife poaching - all of which are attributed to social economic condition of the communities living in the vicinity. A community based conservation program was delivered to strengthen communities' role in maintaining forest integrity while making good income from sustainable agriculture. This action research using mixed methodology evaluates the influence of program delivery in changing the knowledge, attitude and practice of forest protection and sustainable agriculture among beneficiaries in three villages. Data was collected using structured interview, while other supporting information was taken from project reports and field notes. The Wilcoxon Signed Rank Test reveals that program has influence in changing the knowledge of respondents in both forest protection and sustainable agriculture, as well as in the change of attitude and practice regarding sustainable agriculture. However, it does not have influence in changing their attitude and practice toward forest protection. As shwon by economic indicator, program has contributed in providing new source of income to farmers household. The result of logistic regression shows that age, education, land ownership and income has influence in the change of people's knowledge about forest biodiversity. Only age has influence in change of attitude towards sustainable agriculture, and only land ownership has influence on support to forest protection.
\end{abstract}

How to cite (CSE Style $8^{\text {th }}$ Edition):

Widyanto A, Mulatsih S, Karlinasari L. 2018. Pemberdayaan Masyarakat Dalam Pelestraian Hutan dan Pertanian Berkelanjutan di Sekitar Suaka Margasatwa Karakelang, Sulawesi Utara. JPSL 9(4): 1019-1031. http://dx.doi.org/10.29244/jps1.9.4.1019-1031.

\section{PENDAHULUAN}

Pengelolaan hutan di Indonesia telah sejak lama menghadapi tantangan yang kompleks karena interaksinya dengan aspek sosial ekonomi lokal. Belum kokohnya pondasi ekonomi pedesaan menyebabkan ketergantungan warga desa terhadap sumber daya hutan tinggi. Banyaknya jumlah desa yang berbatasan dengan kawasan hutan menimbulkan interaksi yang kuat antara masyarakat dengan hutan. Terdapat sejumlah 31,957 desa yang berinteraksi dengan hutan, dimana 71.06 persennya mengandalkan hutan sebagai sumber penghidupannya (BPS 2009). 
Suaka margasatwa (SM) Karakelang merupakan salah satu kawasan konservasi di Propinsi Sulawesi Utara yang ditetapkan dengan SK Menteri Kehutanan dan Perkebunan Nomor 97/Kpts-II/2000 dan mencakup area seluas 24,669 Ha. Kawasan ini selain memiliki tipe habitat unik berupa hutan hujan dataran rendah dan pegunungan yang tumbuh di atas tanah karst, juga menyimpan keragaman hayati khas kepulauan Talaud. SM Karakelang dihuni beberapa satwa endemis yang hanya terdapat di pulau ini, yaitu Nuri talaud, Kupu-kupu sayap burung talaud, Kuskus beruang talaud dan lain-lain. Nilai penting Karakelang bagi pelestarian keragaman hayati endemis menjadi alasan ditetapkannya secara global sebagai Key Biodivesity Area (CEPF 2014).

Di Kabupaten Kepulauan Talaud, dari sebanyak 142 desa yang ada, 104 desa diantaranya berbatasan dengan kawasan hutan, baik hutan konservasi, hutan lindung maupun hutan produksi. Khusus di Pulau Karakelang, dari 99 desa yang ada, 80 diantaranya berbatasan dengan kawasan hutan, baik suaka margasatwa maupun hutan lindung. Tiga diantara 80 desa yang berbatasan dengan kawasan hutan tersebut adalah Ambela, Bengel dan Rae Selatan (BPS 2017).

Warga di tiga desa biasa memanfaatkan hasil hutan, seperti kayu bakar dan jamur maupun tanaman obat. Sesekali masyarakat juga mengambil kayu untuk bangunan meskipun dilarang oleh petugas suaka margasatwa. Selain itu, beberapa warga memiliki profesi sampingan menangkap burung untuk dijual ke penadah dari luar desa (IDEP 2016).

Data dari situs daring pemantauan hutan Global Forest Watch (2018) mengungkapkan laju penurunan tutupan vegetasi di Kepulauan Talaud, yang mencakup tiga pulau utama Karakelang, Kabaruan dan Salibabu, adalah sebesar 4,457 Ha selama kurun 2001 sampai 2017. Sementara itu laju penambahan tutupan hutan sebesar 1,320 Ha pada kurun 2001 hingga 2012. Sebaran lokasi forest loss tidak hanya di daerah perkebunan melainkan juga di dalam kawasan hutan. Data ini mengonfirmasi laporan masih dijumpainya aktivitas perambahan hutan untuk perladangan berpindah oleh masyarakat di sekitar kawasan hutan (IDEP 2016).

Warga Desa Ambela, Bengel dan Rae Selatan umumnya bermata pencaharian petani, baik petani sayur dan padi (tanaman semusim) maupun petani kebun (kelapa, pala, cengkih). Penurunan kepemilikan lahan pertanian karena meningkatnya jumlah penduduk dengan sendirinya mengurangi produksi pertanian. Sementara itu, program pertanian yang dilaksanakan pemerintah umumnya hanya bertumpu pada penggunaan pupuk dan pestisida kimia. Penggunaan pupuk dan pestisida berlebihan lambat laun justru menyebabkan pertanian tidak berkelanjutan (unsustainable agriculture) oleh menurunnya kesuburan tanah dan kesehatan ekosistem pertanian, karena sifat dan daya kerja pestisida sebagai racun (Winarto, 1999). Program pemberdayaan telah dilakukan untuk memperkuat kapasitas masyarakat dalam pelestarian keragaman hayati, pertanian berkelanjutan dan usaha ekonomi.

Berdasarkan uraian di atas, terdapat dua permasalahan yang diteliti yaitu; (1) apakah program pemberdayaan berpengaruh terhadap perubahan pengetahuan, sikap dan perilaku masyarakat dalam pelestarian hutan dan pertanian berkelanjutan, serta pendapatannya, dan (2) faktor-faktor sosial ekonomi yang manakah yang berpengaruh terhadap perubahan pengetahuan, sikap dan perilaku masyarakat dalam pelestarian hutan dan pertanian berkelanjutan.

Penelitian ini bertujuan untuk: (1) mengevaluasi pengaruh program pemberdayaan terhadap perubahan pengetahuan, sikap dan perilaku masyarakat dalam pelestarian keragaman hayati dan pertanian berkelanjutan, serta pendapatannya, dan (2) menganalisis faktor-faktor yang berpengaruh terhadap perubahan pengetahuan, sikap dan perilaku masyarakat dalam pelestarian keragaman hayati dan pertanian berkelanjutan. 


\section{METODE}

\section{Lokasi dan Waktu Penelitian}

Penelitian ini merupakan riset aksi, bagian dari pelaksanaan program konservasi dan pemberdayaan masyarakat yang dilaksanakan mulai awal tahun 2016 hingga akhir 2018. Penelitian dilakukan di tiga desa di sekitar SM Karakelang, Kabupaten Kepulauan Talaud, Provinsi Sulawesi Utara, yaitu Desa Ambela, Bengel, dan Rae Selatan.

\section{Metode Pengumpulan Data}

Penelitian ini menggunakan metode gabungan (mixed methods) antara kualitatif dan kuantitatif sebagaimana dinyatakan oleh Cameron (2015) serta Saraswati dan Dharmawan (2014). Data yang sifatnya kuantitatif maupun yang dikuantifikasi menjelaskan volume atau intensitas dari suatu variabel. Sementara data kualitatif menerangkan konteks serta hubungan sebab-akibat secara lebih utuh, yang merupakan hal kunci dalam riset-aksi pemberdayaan masyarakat (Indiahono 2016).

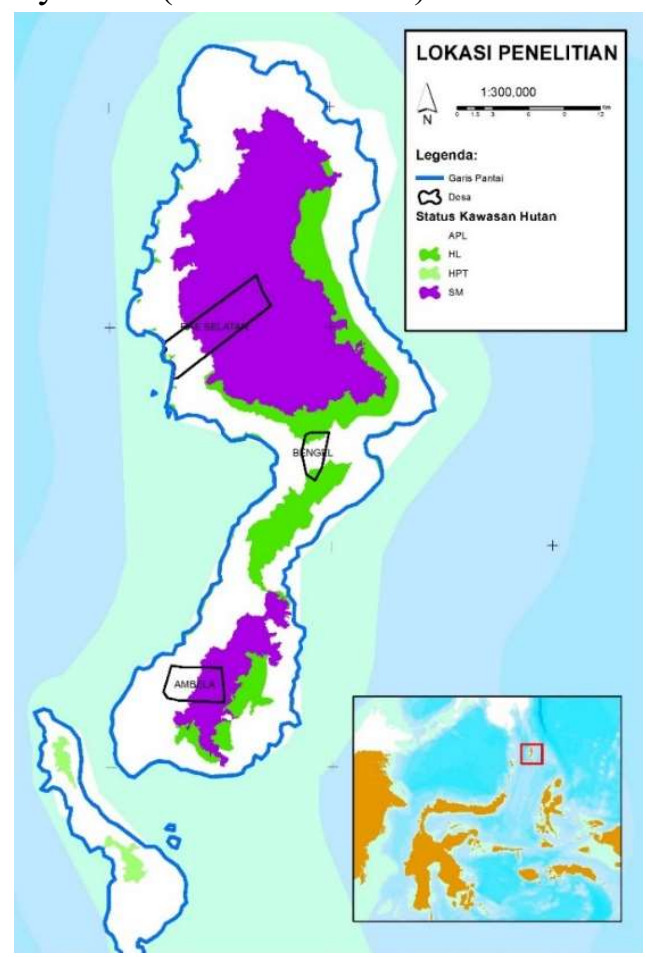

Gambar 1 Peta lokasi penelitian di Pulau Karakelang, Sulawesi Utara.

Penelitian ini menggunakan data primer terkait sembilan variable yang mewakili pengetahuan atau knowledge $(\mathrm{K})$, sikap atau attitude $(\mathrm{A})$ dan perilaku atau practice $(\mathrm{P})$ responden terhadap pelestarian hutan dan pertanian berkelanjutan (Tabel 1). Data K, A dan P dikumpulkan selama pelaksanaan program dari tahun 2016 hingga 2017 melalui wawancara terhadap 27 responden. Sedangkan data peningkatan pendapatan masyarakat didapatkan dari laporan keuangan kelompok usaha ekonomi di tiga desa.

Wawancara juga menggali data faktor-faktor sosial ekonomi responden yang mencakup usia, pendidikan, luas lahan yang dimiliki serta jumlah tanggungan anggota keluarga sebagaimana juga dikaji oleh Timban (2005), Wahyudi (2004), dan Sujarwo (2004). 
Tabel 1 Variabel penelitian terkait pengetahuan, sikap dan perilaku pada aspek pelestarian hutan dan pertanian berkelanjutan

\begin{tabular}{|c|c|c|c|}
\hline \multirow{2}{*}{ Aspek } & \multicolumn{3}{|c|}{ Variabel } \\
\hline & Pengetahuan (K) & Sikap (A) & Perilaku (P) \\
\hline $\begin{array}{l}\text { Pelestarian } \\
\text { hutan }\end{array}$ & $\begin{array}{l}\text {-Fungsi hutan (K1) } \\
\text {-Aturan pengelolaan hutan (K2) } \\
\text {-Keragaman hayati hutan (K3) }\end{array}$ & $\begin{array}{l}\text { Tanggung jawab } \\
\text { pelestarian hutan (A1) }\end{array}$ & $\begin{array}{l}\text { Peran dalam } \\
\text { perlindungan hutan } \\
\text { (P1) }\end{array}$ \\
\hline $\begin{array}{l}\text { Pertanian } \\
\text { berkelanjutan }\end{array}$ & $\begin{array}{l}\text {-Arti Pertanian Berkelanjutan (K4) } \\
\text {-Tujuan Pertanian Berkelanjutan (K5) }\end{array}$ & $\begin{array}{l}\text { Minat terhadap } \\
\text { pertanian } \\
\text { berkelanjutan (A2) }\end{array}$ & $\begin{array}{l}\text { Praktik pertanian } \\
\text { berkelanjutan }(\mathrm{P} 2)\end{array}$ \\
\hline
\end{tabular}

\section{Metode Analisis Data}

\section{Analisis Deskriptif}

Data kuesioner pengetahuan, sikap dan perilaku yang dikumpulkan lewat wawancara responden di Desa Ambela, Bengel, dan Rae Selatan diolah untuk dilakukan analisis deskriptif. Data dikuantifikasi dengan cara diberikan skor untuk mendukung tahap analisis berikutnya. Sedangkan data sosial ekonomi responden disusun ke dalam database spreadsheet dan dianalisis untuk melihat nilai frekuensi, rerata dan prosentasenya.

\section{Analisis Statistik Uji Beda}

Untuk mengetahui pengaruh program terhadap perubahan pengetahuan, sikap dan perilaku responden dilakukan uji beda dengan dua hipotesis, yaitu H0 jika tidak ada perubahan, dan H1 jika terjadi perubahan, antara sebelum dan setelah adanya program. Kesembilan variabel di atas dianalisis signifikansi perubahannya menggunakan Wilcoxon Signed Rank Test pada software SPSS. Pengujian dengan Wilcoxon test dilakukan untuk jenis data yang memiliki dua dimensi tetapi dengan saling keterkaitan. Dalam hal ini data pengetahuan, sikap dan perilaku berasal dari responden yang sama tetapi diambil pada waktu yang berbeda, yaitu di awal dan di akhir program.

Selanjutnya penghitungan oleh software memberikan nilai $Z$ dan $\mathrm{p}$ (Asymp.Sig 2 tailed). Jika nilai $\mathrm{p}<$ 0.05 maka tolak H0 (terima H1), artinya terdapat perbedaan yang nyata antara data awal (Baseline) dengan akhir (Endline).

\section{Analisis Statistik Regresi Logistik}

Analisis regresi logistik dilakukan untuk mengetahui faktor-faktor yang berpengaruh terhadap perubahan perilaku responden terkait pelestarian hutan dan pertanian berkelanjutan. Regresi logistik merupakan metode yang layak dipilih untuk memprediksi variabel terikat yang berskala dikotomi. Skala dikotomi atau kategori yang dimaksud dalam hal ini, yaitu Ya (berpengaruh, nilai 1) atau Tidak (tidak berpengaruh, nilai 0).

\section{HASIL DAN PEMBAHASAN}

\section{Profil Responden Penelitian}

Jumlah responden di tiga desa yang mengikuti wawancara di awal dan di akhir program adalah masingmasing sebanyak 72 orang dan 61 orang. Namun demikian hanya ada 27 orang responden yang terlibat baik di pengambilan data awal maupun akhir (Tabel 2). Dalam perjalanan program, banyak responden yang tidak lagi aktif dan digantikan oleh responden baru yang bergabung belakangan. Responden yang mengikuti pengembangan usaha industri makanan rumah tangga sebanyak 22 orang. 
Tabel 2 Jumlah responden penelitian dan faktor-faktor sosial ekonomi.

\begin{tabular}{lccc}
\hline \multirow{2}{*}{ Faktor sosial ekonomi } & \multicolumn{3}{c}{ Desa } \\
\cline { 2 - 4 } & Ambela & Bengel & Rae Selatan \\
\hline Usia rata-rata (tahun) & 46.6 & 46.4 & 49.6 \\
Luas lahan rata-rata (Ha) & 1.6 & 0.4 & 0.5 \\
Pendidikan (\% total) & & & \\
$-\quad$ SD & 21.4 & 0.0 & 0.0 \\
$-\quad$ SMP & 35.7 & 40.0 & 62.5 \\
$-\quad$ SMA & 35.7 & 60.0 & 37.5 \\
Jumlah tanggungan rata-rata (orang) & 2.9 & 2.8 & 2.4 \\
\hline Jumlah responden (orang) & 14 & 5 & 8 \\
\hline
\end{tabular}

\section{Pengaruh Program terhadap Perubahan Pengetahuan, Sikap dan Perilaku}

\section{Pengetahuan}

Berdasarkan hasil uji beda dengan Wilcoxon test (Tabel 3), terlihat bahwa secara umum terjadi perubahan pengetahuan responden antara sebelum dengan sesudah program dilaksanakan. Ini ditunjukkan oleh nilai Asymp.Sig. yang berada di bawah 5 persen pada tiap-tiap variabel pengetahuan (K1 - K5). Di sini dapat disimpulkan bahwa program memberikan pengaruh nyata terhadap meningkatnya pengetahuan para penerima manfaat (beneficiaries) yang menjadi responden penelitian. Hasil ini sejalan dengan penelitin Wahyudi (2004) yang menyatakan bahwa keaktifan dalam kelompok berpengaruh terhadap meningkatnya pengetahuan warga dalam pelestarian hutan.

Bila dilihat rinci ke masing-masing desa, perubahan yang terjadi tidaklah seragam. Diantara tiga desa, perubahan pengetahuan yang paling signifikan terjadi pada responden di Desa Ambela dimana nilai Asymp.Sig semua P kurang dari 5 persen. Oleh karenanya, dapat disimpulkan bahwa pelaksanaan program telah meningkatkan pengetahuan responden di Ambela secara signifikan.

Di Desa Bengel dan Desa Rae Selatan, perubahan pengetahuan terjadi pada sebagian aspek, tidak seluruhnya. Hal tersebut ditunjukkan oleh nilai Asymp.Sig. yang sebagian berada di bawah sedangkan lainnya di atas 0.05. Nilai Asymp.Sig yang cenderung tinggi dikontribusikan oleh variabel-variabel yang berkaitan dengan kawasan hutan (K1 - K3). Ini berarti program kurang memberi pengaruh terhadap perubahan pengetahuan terkait pengelolaan hutan, terutama di Bengel dan Rae Selatan. Ini disebabkan aspek pelestarian hutan kurang menjadi fokus program di tahap awal.

Tabel 3 Hasil analisis statistik uji beda perubahan pengetahuan responden ${ }^{\text {a }}$

\begin{tabular}{|c|c|c|c|c|c|c|}
\hline Desa & Parameter & K1 & K2 & K3 & K4 & K5 \\
\hline$\overline{\text { Semua }}$ & $\mathrm{Z}$ & $-3.448^{b}$ & $-2.828^{b}$ & $-3.317^{b}$ & $-4.243^{b}$ & $-2.972^{b}$ \\
\hline Desa & Asymp. Sig. (2-tailed) & 0.001 & 0.005 & 0.001 & 0.000 & 0.003 \\
\hline \multirow{2}{*}{ Ambela } & $\mathrm{Z}$ & $-2.598^{\mathrm{b}}$ & $-2.236^{\mathrm{b}}$ & $-2.458^{\mathrm{b}}$ & $-3.207^{\mathrm{b}}$ & $-2.333^{\mathrm{b}}$ \\
\hline & Asymp. Sig. (2-tailed) & 0.009 & 0.025 & 0.014 & 0.001 & 0.020 \\
\hline \multirow{2}{*}{ Bengel } & $\mathrm{Z}$ & $-1.342^{\mathrm{b}}$ & $-1.732^{b}$ & $-1.732^{\mathrm{b}}$ & $-2.000^{\mathrm{b}}$ & $-2.000^{\mathrm{b}}$ \\
\hline & Asymp. Sig. (2-tailed) & 0.180 & 0.083 & 0.083 & 0.046 & 0.046 \\
\hline Rae & $\mathrm{Z}$ & $-2.530^{\mathrm{b}}$ & $0.000^{c}$ & $-1.656^{\mathrm{b}}$ & $-2.449^{b}$ & $-1.000^{\mathrm{b}}$ \\
\hline Selatan & Asymp. Sig. (2-tailed) & 0.011 & 1.000 & 0.098 & 0.014 & 0.317 \\
\hline
\end{tabular}

${ }^{a}$ Wilcoxon Signed Ranks Test

${ }^{\mathrm{b}}$ Based on negative ranks.

${ }^{\mathrm{c}}$ The sum of negative ranks equals the sum of positive ranks 
Sementara itu variabel yang berkaitan dengan pertanian berkelanjutan (K4, K5) sebagian besar nilai Asymp.Sig.nya kurang dari 5 persen (signifikan). Artinya program telah berhasil mempengaruhi pengetahuan masyarakat berkaitan dengan pertanian berkelanjutan. Meskipun program ini bertujuan melestarikan keragaman hayati, tetapi target jangka pendeknya membangun kapasitas masyarakat dalam pertanian dan ekonomi. Alokasi sumber daya program lebih banyak di pelatihan dan pendampingan pertanian dan usaha ekonomi.

Pada masyarakat Ambela, peningkatan pengetahuan cukup signifikan pada semua variabel pengetahuan. Faktor yang memungkinkan ini adalah karakter terbuka masyarakat terhadap pengetahuan atau hal baru. Warga Ambela adalah campuran migran dari Siau, Miangas dan Sangihe, sehingga sedari asalnya mereka sudah terbiasa berinteraksi dengan orang dari luar kelompoknya. Ini berbeda dengan warga Bengel yang seluruhnya adalah migran dari Siau dan warga Rae Selatan yang orang asli Talaud (IDEP 2016). Selain itu, dibanding dua desa lainnya, Ambela paling banyak memiliki warga yang bekerja sebagai pegawai negeri serta karyawan swasta (BPS 2017). Jenis pekerjaan tersebut banyak melibatkan interaksi dengan pihak di luar desa sehingga membuka arus informasi alternatif yang lalu terdifusi dalam kehidupan sosial desa.

Karakter terbuka masyarakat Ambela juga ditunjukkan oleh lebih banyaknya anggota kelompok yang aktif di Ambela dibanding di desa-desa yang lain. Di Ambela, anggota kelompok permakultur ada 16 orang yang aktif menjalankan praktek pertanian berkelanjutan selama lebih kurang dua belas bulan. Mereka aktif mempraktekkan tahap-tahap uji coba mulai dari penyiapan lahan, pembuatan pupuk kompos dan cair, pembibitan, hingga perawatan tanaman. Dalam daur program mereka mengalami dua kali panen beberapa komoditi seperti cabai, tomat, terung, kacang-kacangan, sayuran, dan lain-lain. Hal-hal tersebut yang dimaksud sebagai faktor ketereksposan dalam penelitian Sujarwo (2004) dan dinilai mempengaruhi tingginya pengetahuan umum masyarakat.

Di sisi lain, kelompok Ambela juga memiliki ketua yang sekaligus inspirator bagi kelompok. Beliau adalah seorang pensiunan pendidik yang berpengetahuan luas dan punya visi atas desanya. Ketua kelompok adalah orang yang aktif mengembangkan inisiatif baru berdasarkan pelatihan dari tim program. Beliau mampu mempromosikan kompos dan pupuk cair produksi kelompok menjadi komoditi yang dibeli oleh petani dari desa lain. Ini merupakan inovasi yang dilakukan sendiri oleh kelompok karena program hanya memberikan pelatihan cara pembuatannya, tanpa ada dorongan untuk memasarkannya sebagai komoditi. Sebagaimana diulas dalam Timban (2005) kepemimpinan berperan besar untuk menggerakkan partisipasi anggota kelompok.

Sementara itu, Desa Bengel seluruhnya berisi warga migran dari Pulau Siau, Kabupaten Sitaro, Sulawesi Utara. Di tempat asalnya, mereka umumnya adalah petani pala. Pala tumbuh hampir tanpa perawatan bahkan secara alami banyak ditemukan di dalam hutan. Petani pala tidak perlu rutin menyiangi rumput atau menjaga buah pala dari hewan pemangsa. Mereka hanya sibuk ketika musim panen. Sering dikatakan bahwa petani pala dimanjakan oleh alam sehingga memiliki karakter sulit berubah dan lambat menerima hal baru. Meskipun kepala desa sendiri turun tangan dalam kegiatan dan menjadi ketua kelompok, partisipasi warga Bengel dalam kelompok belum maksimal. Dari awal hanya sebanyak 11 orang warga Bengel yang ikut dalam kelompok permakultur. Meski demikian, ke sebelas orang ini rajin mengikuti tahap-tahap uji coba pertanian alami dan memetik hasil yang sama seperti rekan-rekannya di Ambela (IDEP 2017).

Memang diantara desa-desa lainnya, warga Bengel termasuk yang kurang beruntung. Ketika pindah sebagai migran di Talaud, mereka mengaku tidak mendapatkan jatah lahan yang memadai untuk berkebun tanaman tahunan sebagaimana mereka praktekkan di tempat asalnya. Mereka pun tidak punya budaya bertanam tanaman semusim seperti sayuran dan palawija yang mestinya bisa dilakukan di lahan pekarangan. Banyak warga Bengel yang lebih memilih bekerja menjadi buruh tani di kebun-kebun milik warga desa lain dari pada harus merintis jenis mata pencaharian baru yang sesuai situasinya kini. Ini juga menandakan karakter yang cenderung pasrah terhadap keadaan. Karakter-karakter tersebut mungkin sedikit banyak berpengaruh terhadap respon warga Bengel terhadap program. 
Rae Selatan adalah desa asli Talaud yang warganya telah menetap turun-temurun di Pulau Karakelang. Warga Rae Selatan adalah tipikal khas masyarakat tepi hutan yang punya interaksi kuat dengan kawasan hutan. Mereka bahkan punya budaya terkait hutan, dalam bentuk pengkeramatan satu wilayah tertentu untuk ritual adat. Tidak boleh ada orang yang memasuki kawasan itu jika bukan untuk acara adat.

Namun seiring waktu, penduduk makin banyak sementara luas lahan tetap. Selain itu, pola pemenuhan kebutuhan warga pun berubah menjadi lebih tergantung pada produk-produk pasar dan bukan produk yang dapat mereka hasilkan sendiri. Lama kelamaan, kearifan mulai tergerus oleh budaya instan. Pengetahuan mereka tentang kawasan hutan saat ini lebih banyak termanfaatkan untuk tujuan-tujuan eksploitatif, seperti menebang pohon dan menjerat burung atau satwa lainnya.

Tak beda dengan masyarakat lainnya, arus globalisasi membuat warga Rae Selatan semakin berorientasi ekonomi jangka pendek. Mereka sering menerima pesanan dari kota atau desa lainnya mencari bahan baku kayu dari hutan. Sama dengan warga Bengel, mereka juga sering menangkap satwa liar seperti Nuri talaud jika ada yang memesannya. Program pemberdayaan yang tidak serta merta memberikan keuntungan finansial, awalnya tidak banyak diminati. Mereka yang ikut dalam kelompok adalah sebagian kecil dari warga yang masih memiliki sikap positif terhadap pengetahuan baru.

\section{Sikap}

Uji beda pada indikator-indikator sikap (A1, A2) memberikan hasil yang tidak sama (Tabel 4). Perubahan sikap responden antara di awal dan di akhir program tidak signifikan pada A1, namun signifikan pada A2. Artinya, program belum mampu merubah secara signifikan sikap warga terkait tanggung jawab pelestarian hutan. Sementara terkait minat kepada pertanian berkelanjutan terjadi peningkatan yang cukup signifikan. Jika dilihat lebih rinci ke masing-masing desa, perubahan sikap ini tidak signifikan dengan semua nilai Asymp.Sig. di atas 5 persen. Hal ini disebabkan karena program yang baru berjalan satu tahun lebih belum bisa merubah sikap responden. Sikap merupakan karakter yang lebih sulit dipengaruhi karena telah terbentuk oleh pengalaman dan proses belajar sepanjang hidup seperti dinyatakan oleh Sarwono (2002). Oleh karenanya merubah sikap seseorang atau sekelompok orang perlu waktu lebih lama dan proses yang tidak selalu linier.

Terlepas dari fokus program yang lebih dominan di pertanian dibanding pelestarian hutan, variabel tanggung jawab (sikap) pelestarian hutan (A1) merupakan hal yang tidak mudah dijawab oleh warga. Meskipun sehari-hari mereka memanfaatkan beberapa hasil hutan, dan ingin tetap seperti itu, tetapi ini tidak dimungkinkan karena suaka margasatwa dikelola hanya untuk tujuan konservasi dan penelitian sehingga tidak ada ruang bagi pemanfaatan oleh warga setempat. Karenanya, jawaban yang cukup dominan saat wawancara baik di awal maupun di akhir program adalah tidak tahu. Dalam Kurniawan (2013) juga dijumpai masyarakat yang sudah lama tinggal dan memanfaatkan sumber daya hutan di Taman Nasional Gunung Halimun Salak cenderung mempertahankan pola tersebut meskipun aturan melarangnya.

Tabel 4 Hasil analisis statistik uji beda perubahan sikap responden.

\begin{tabular}{llrr}
\hline Desa & Parameter & $\mathrm{A} 1$ & $\mathrm{~A} 2$ \\
\hline Semua Desa & Z & $-1.155^{\mathrm{b}}$ & $-2.000^{\mathrm{c}}$ \\
& Asymp. Sig. (2-tailed) & 0.248 & 0.046 \\
Ambela & Z & $-1.342^{\mathrm{b}}$ & $-1.732^{\mathrm{c}}$ \\
& Asymp. Sig. (2-tailed) & 0.180 & 0.083 \\
Bengel & Z & $-1.414^{\mathrm{b}}$ & $0.000^{\mathrm{d}}$ \\
& Asymp. Sig. (2-tailed) & 0.157 & 1.000 \\
Rae Selatan & Z & $-0.447^{\mathrm{c}}$ & $-1.000^{\mathrm{c}}$ \\
& Asymp. Sig. (2-tailed) & 0.655 & 0.317 \\
\hline
\end{tabular}

${ }^{\mathrm{d}}$ The sum of negative ranks equals the sum of positive ranks. 
Pada variabel A2, meskipun masyarakat memiliki antusiasme yang tinggi terhadap uji coba pertanian organik tetapi uji beda menunjukkan perubahan sikap yang tidak signifikan. Ini disebabkan skor di awal memang sudah tinggi, tidak begitu berbeda dengan skor akhir. Artinya sejak awal memang masyarakat sudah tertarik dengan praktek pertanian berkelanjutan (permakultur). Demikian pula di akhir program, mereka tetap antusias dengan permakultur karena telah membuktikan hasilnya.

\section{Perilaku}

Selanjutnya uji beda pada aspek perilaku (P1, P2) hasilnya menunjukkan nilai Asymp.Sig. P1 yang tidak signifikan $(>0.05)$. Ini disebabkan karena sejak awal skor indikator ini sudah tinggi. Responden rata-rata menyatakan telah ikut menjaga kelestarian hutan (P1) baik pada survey sebelum maupun sesudah pelaksanaan program (Tabel 5).

Sedangkan perbedaan nilai P2 yang signifikan memang karena terjadi perubahan nilai awal dengan akhir. Di awal program, hampir seluruh responden menyatakan menggunakan pupuk dan pestisida kimia dalam usaha pertaniannya. Di akhir program, sebagian besar menyatakan sudah tidak menggunakan pupuk dan pestisida kimia.

Pada masing-masing desa nampak perubahan perilaku yang signifikan antara sebelum dengan sesudah dilaksanakannya program. Meski demikian, perubahan tidak terjadi pada setiap variabel perilaku. Di Desa Ambela dan Bengel, perubahan terjadi berkaitan dengan melaksanakan pertanian berkelanjutan, yang ditunjukkan dengan tidak lagi memakai pupuk dan pestisida kimia, melainkan menggunakan nutrisi dan pengendali hama alami, serta berbagai teknik pengolahan tanah secara permakultur.

Sedangkan di Desa Rae Selatan, baik antara sebelum maupun sesudah program tidak ada perubahan perilaku yang berarti pada taraf 0.05 . Artinya, tetap terjadi perubahan perilaku meskipun tidak sebesar yang terjadi di Ambela dan Bengel. Hal ini disebabkan memang sudah ada responden yang bertani tanpa menggunakan pupuk dan pestisida kimia. Ini tentunya mengurangi perbedaan antara nilai P2 di awal dan di akhir program.

Warga Rae Selatan adalah orang asli Talaud yang masih memiliki sisa-sisa kearifan lokal, termasuk dalam kegiatan pertanian. Beberapa warga yang kini telah lanjut usia masih mengalami era dimana pertanian dijalankan tanpa pupuk dan pestisida kimia. Mereka menjalankan praktek pertanian sebagaimana yang diajarkan oleh leluhurnya secara turun-temurun. Hanya saja kearifan ini telah mulai luntur karena sebagian besar petani di Rae juga menggunakan pupuk dan obat kimia seperti halnya warga desa lain di Talaud.

Tabel 5 Hasil analisis statistik uji beda perubahan perilaku responden.

\begin{tabular}{llrr}
\hline Desa & Parameter & \multicolumn{1}{c}{$\mathrm{P} 1$} & $\mathrm{P} 2$ \\
\hline Semua Desa & $\mathrm{Z}$ & $-1.342^{\mathrm{b}}$ & $-4.472^{\mathrm{b}}$ \\
& Asymp. Sig. (2-tailed) & 0.180 & 0.000 \\
Ambela & $\mathrm{Z}$ & $0.000^{\mathrm{b}}$ & $-3.464^{\mathrm{c}}$ \\
& Asymp. Sig. (2-tailed) & 1.000 & 0.001 \\
Bengel & $\mathrm{Z}$ & $-1.414^{\mathrm{c}}$ & $-2.236^{\mathrm{c}}$ \\
& Asymp. Sig. (2-tailed) & 0.157 & 0.025 \\
Rae Selatan & $\mathrm{Z}$ & $-0.577^{\mathrm{c}}$ & $-1.732^{\mathrm{c}}$ \\
& Asymp. Sig. (2-tailed) & 0.564 & 0.083 \\
\hline
\end{tabular}

Selain faktor tersebut, memang ada responden anggota kelompok yang masih menggunakan pupuk dan pestisida kimia di lahan non-pekarangan. Pada fase pertama $(2016$ - 2017) program memang baru melakukan uji coba pertanian organik di lahan pekarangan dan belum mencakup lahan kebun. Sementara itu, sebagian besar lahan pertanian di Talaud adalah perkebunan tanaman tahunan seperti kelapa, cengkeh dan pala. Tanaman kelapa dirawat dengan penggunaan pestisida yang tinggi untuk mengendalikan serangan hama belalang sexava. Dapat dipahami, pada akhir proyek tahap pertama ini warga belum mendapatkan solusi atas permasalahan pestisida di kebun mereka. Perluasan wilayah program di lahan perkebunan baru dilakukan di tahap kedua 
(2017 - 2018) program, dimana mulai diperkenalkan pengendalian hama terpadu bekerja sama dengan pemerintah desa dan Dinas Pertanian Kabupaten Talaud.

Pada aspek keikutsertaan dalam pelestarian hutan (P1), baik di Ambela, Bengel maupun Rae Selatan tidak terjadi perbedaan yang signifikan antara di awal dan di akhir program. Warga di tiga desa umumnya menyatakan mereka ikut menjaga hutan dengan tidak melakukan perusakan. Apa yang mereka rujuk sebagai perusakan dalam hal ini adalah tindakan merugikan kelestarian hutan yang masif seperti illegal logging dan perambahan kawasan hutan. Sementara mengambil hasil hutan untuk kebutuhan sehari-hari (subsistensi) bagi mereka adalah wajar, bukan dianggap tindakan yang merusak. Perilaku masyarakat sekitar hutan yang cenderung memanfaatkan hasil hutan juga diulas dalam Khalik et al (2011).

Warga setempat memiliki referensi terkait kegiatan yang merusak kawasan hutan. Ada satu desa di tepi kawasan suaka margasatwa yang melakukan perambahan hutan untuk dijadikan lahan berkebun. Kejadian ini sudah berlangsung cukup lama namun belum ditangani tuntas. Tindakan yang sudah pernah dilakukan oleh Balai KSDA resort Karakelang Selatan adalah teguran kepada para pelaku perambahan. Namun sejauh ini tindakan tersebut belum efektif menghentikan aksi perusakan yang terjadi. Para peladang masih menduduki lahan yang dibukanya. Menurut warga, terutama Ambela yang berada paling dekat dengan lokasi perambahan, kegiatan semacam itu yang tergolong mengancam kelestarian hutan.

\section{Pengaruh program terhadap peningkatan pendapatan}

Program pemberdayaan bidang ekonomi diikuti oleh 22 orang dari tiga desa. Mereka tergabung dalam tiga buah kelompok yang dibentuk di masing-masing desa, yaitu kelompok SEHATI Desa Ambela, kelompok LESTARI Desa Bengel, dan kelompok DANDILING Desa Rae Selatan. Usaha yang dilakukan meliputi pembuatan makanan jadi seperti minyak kelapa murni, keripik pisang dan sayur, serta pembuatan souvenir dari bahan daur ulang. Selain itu, beberapa anggota kelompok secara mandiri memproduksi pupuk cair yang dipasarkan ke warga lainnya bahkan hingga ke luar desa. Data omset usaha dan pendapatan anggota ditampilkan pada Tabel 6.

Kelompok SEHATI Desa Ambela memiliki omset usaha paling besar diantara ketiga kelompok, sementara kelompok DANDILING Desa Rae Selatan omsetnya paling kecil. Namun demikian, kelompok LESTARI Desa Bengel memiliki omset per kapita yang paling besar sehingga anggota kelompok memperoleh pendapatan rata-rata paling besar.

Anggota kelompok DANDILING memperoleh pendapatan rata-rata paling kecil meskipun jumlah hari kerjanya paling banyak. Hal ini terutama disebabkan oleh strategi pemasaran produk yang kurang ekspansif. Kelompok DANDILING hanya memasarkan produknya di dalam dan sekitar desanya sehingga daya jualnya tidak tinggi. Ini berbeda dengan kelompok LESTARI dan kelompok SEHATI yang sama-sama memasarkan produk ke kota kecamatan, yaitu Beo dan Melonguane, dimana lebih besar peluang bertemu pembeli. Selain itu, kelompok DANDILING memiliki masalah kepemimpinan yang mempengaruhi stabilitas produksi. Dalam penelitian Timban (2005) disimpulkan bahwa kepemimpinan yang efektif sangat berperan pada partisipasi anggota dalam kegiatan kelompok.

Tabel 6 Hasil Usaha Pengolahan Makanan oleh Tiga Kelompok.

\begin{tabular}{lcccccc}
\hline Desa & $\begin{array}{l}\text { Omset Usaha } \\
\text { (Rp) }\end{array}$ & $\begin{array}{l}\text { Jumlah } \\
\text { anggota }\end{array}$ & $\begin{array}{l}\text { Omset per } \\
\text { kapita (Rp) }\end{array}$ & $\begin{array}{l}\text { Pendapatan } \\
\text { rerata anggota }\end{array}$ & $\begin{array}{l}\text { rerata hari } \\
\text { kerja anggota }\end{array}$ & $\begin{array}{l}\text { Pendapatan anggota } \\
\text { per hari kerja (Rp) }\end{array}$ \\
\hline Ambela & 15792000 & 10 & 1579200 & 982500 & 8.2 & 161959.85 \\
Bengel & 11291000 & 6 & 1881833 & 1151000 & 7 & 167816.40 \\
Rae Selatan & 7825000 & 6 & 1304167 & 612500 & 14.3 & 44505.71 \\
\hline
\end{tabular}


Pada anggota kelompok SEHATI dan LESTARI, pendapatan per hari kerja di atas seratus ribu rupiah merupakan nilai yang tinggi bagi rumah tangga setempat. Volume produksi dari usaha ini memang masih rendah karena belum dijalankan secara penuh waktu, melainkan hanya memanfaatkan waktu luang anggota ketika sedang tidak bekerja kebun. Rata-rata tiap anggota hanya meluangkan waktu antara 1 sampai 3 hari setiap bulan selama delapan bulan menjalankan uji coba usaha ini. Produktivitas usaha ekonomi kelompok perempuan juga dijumpai dalam kajian Indiahono (2016) pada program PNPM Mandiri Perdesaan di Banyumas.

\section{Faktor yang Mempengaruhi Perubahan Pengetahuan, Sikap dan Perilaku}

Pemodelan logit (regresi logistik) menghasilkan hanya variabel K3, A2 dan P1 yang dipengaruhi oleh variabel bebas. Pengetahuan tentang keragaman hayati hutan (K3) dipengaruhi oleh 4 variabel (usia, pendidikan, penghasilan awal, tanggungan akhir). Sementara itu, sikap terhadap pertanian berkelanjutan (A2) dipengaruhi oleh usia, sedangkan keterlibatan dalam perlindungan hutan (P1) dipengaruhi oleh luas lahan.

\section{Faktor yang mempengaruhi perubahan pengetahuan tentang keragaman hayati hutan}

Pada variabel K3 (pengetahuan tentang keragaman hayati hutan), variabel bebas (usia, pendidikan, jumlah tanggungan, penghasilan) secara individu memberikan nilai signifikan di bawah taraf 10 persen (0.1). Artinya, keempat variabel tesebut memiliki pengaruh yang nyata terhadap perubahan pengetahuan responden (Tabel 7). Ini sesuai dengan penelitian Yusmasari (2003) bahwa pendidikan berpengaruh terhadap pengetahuan warga tentang pelestarian hutan, dan penelitian Wahyudi (2004) yang menyatakan bahwa luas lahan tidak berpengaruh terhadap pengetahuan masyarakat dalam pelestarian hutan.

Usia merupakan variabel bebas yang memiliki nilai sig. sebesar 0.050 , artinya berpengaruh terhadap pengetahuan responden tentang kawasan hutan. Jika usia lebih tua 1 tahun maka probabilitas untuk meningkatnya pengetahuan tentang keragaman hayati hutan (K3) adalah sebanyak 1.130 kali. Dalam konteks setempat, hal ini bisa dipahami bahwa orang-orang yang lebih tua usianya, lebih banyak yang bekerja sebagai petani, dimana tidak jarang mereka berada di dekat atau bahkan di dalam kawasan hutan untuk berbagai keperluan. Petani kadang masuk ke hutan mencari madu, mengumpulkan tanaman obat, memeriksa aliran di hulu sungai, dan lain-lain. Ini sejalan dengan hasil penelitian Sujarwo (2004) yang menyatakan umur berpengaruh terhadap pengetahuan masyarakat tentang pelestarian hutan.

Warga yang berusia lebih muda, memang ada yang mengikuti jejak orang tuanya menjadi petani, atau bekerja kebun, tetapi proporsinya lebih rendah dari pada orang-orang pada generasi sebelumnya. Anak muda cenderung mencari pekerjaan selain petani karena pertimbangan kepemilikan lahan, hasil yang didapatkan, serta gengsi. Pekerjaan selain petani (buruh, pegawai) mengharuskan mereka lebih banyak berada di luar desanya, minim interaksi dengan kawasan hutan. Mengikuti model regresi ini maka semakin banyak generasi muda yang akan turun pemahamannya akan keragaman hayati hutan

Tabel 7 Hasil analisis statistik faktor yang berpengaruh pada perubahan K3, A2 dan P1.

\begin{tabular}{|c|c|c|c|c|}
\hline Variabel & Faktor & $\mathrm{B}$ & Sig. & $\operatorname{Exp}(B)$ \\
\hline & Usia & 0.122 & 0.050 & 1.130 \\
\hline Pengetahuan tentang & Pendidikan & 3.859 & 0.006 & 47.423 \\
\hline \multirow{3}{*}{$\begin{array}{l}\text { keragaman hayati hutan } \\
\text { (K3) }\end{array}$} & Jumlah & 3.640 & 0.050 & 38.100 \\
\hline & Tanggungan akhir & & & \\
\hline & Penghasilan awal & -3.455 & 0.087 & 0.032 \\
\hline $\begin{array}{l}\text { Sikap terhadap pertanian } \\
\text { berkelanjutan (A2) }\end{array}$ & Usia & 0.297 & 0.050 & 1.345 \\
\hline $\begin{array}{l}\text { Perilaku terlibat dalam } \\
\text { perlindungan hutan }(\mathrm{P} 1)\end{array}$ & Luas lahan akhir & -2.261 & 0.083 & 0.104 \\
\hline
\end{tabular}


Variabel bebas berikutnya adalah pendidikan yang menunjukkan nilai sig. sebesar $0.006<0.10$, artinya pendidikan mempengaruhi pengetahuan tentang keragaman hayati hutan (K3). Diperjelas dengan nilai $\operatorname{Exp}(\mathrm{B})$ sebesar 47.423 menunjukkan bahwa jika seorang responden pendidikannya lebih tinggi 1 tingkat maka probabilitas terjadinya peningkatan $\mathrm{K} 3$ adalah sebesar 47.230 kali dibanding jika pendidikannya 1 tingkat lebih rendah. Penjelasan konteksnya, bagi warga tepi hutan, antara hutan dengan kebun kadang tidak begitu dibedakan. Tidak jarang mereka menyebut hutan padahal yang dimaksud adalah kebun. Ini tidak hanya terjadi di Talaud, atau Sulawesi Utara, melainkan fenomena yang umum termasuk di warga desa di Pulau Jawa. Kata hutan mereka gunakan untuk menyebut kebun karena biasanya kebun mereka adalah kebun campuran yang terdiri dari bermacam-macam jenis tumbuhan (bukan monokultur). Ini dibuktikan di kuesioner, tidak jarang responden menyebutkan cengkeh, pala dan kelapa sebagai jenis tumbuhan yang terdapat di dalam kawasan hutan.

Pemaknaan demikian muncul diantara mereka yang punya interaksi cukup kuat dengan kawasan hutan. Dulu sebelum kawasan hutan ditetapkan pemerintah kolonial, tidak ada batas yang tegas antara kebun dan hutan. Warga pun dapat menggarapnya secara gilir balik (swidden agriculture) sejauh mereka mampu (Suyodono et al. 2014). Pemahaman dan praktek ini diajarkan turun temurun dan membekas dalam cara penyebutan hutan.

Akan tetapi, mereka yang berpendidikan lebih tinggi tahu membedakan kebun dan hutan dengan tegas. Karenanya mereka dapat membedakan dengan lebih tepat antara keragaman hayati yang ada di hutan dengan yang ada di kebun. Ini sejalan dengan penelitian Sujarwo (2004) bahwa pendidikan berpengaruh terhadap pengetahuan tentang pelestarian hutan.

Variabel penghasilan awal menunjukkan nilai sig. sebesar $0.087<0.10$, artinya penghasilan mempengaruhi P3. Namun demikian nilai $\operatorname{Exp(B)}$ sebesar 0,032 menunjukkan bahwa jika seseorang penghasilannya lebih tinggi 1 tingkat maka peluang seseorang tersebut ada peningkatan P3 justru sebesar 0,032 dari yang penghasilannya 1 tingkat dibawahnya. Penghasilan yang sudah tinggi membuat orang cenderung fokus dengan pekerjaan atau usahanya, dan tidak tertarik terlibat dalam pengelolaan hutan.

Di kalangan warga desa tepi hutan, mereka yang memiliki penghasilan tinggi lebih tidak termotivasi untuk berkegiatan di kawasan hutan. Memasuki kawasan hutan membutuhkan tenaga yang cukup besar karena jaraknya cukup jauh dari kampung. Jika mereka cukup mampu maka akan cenderung membayar jasa tetangganya untuk mendapatkan sesuatu yang ada di hutan, misalnya kayu.

\section{Faktor yang mempengaruhi perubahan sikap dalam pertanian berkelanjutan}

Regresi logistik variabel A2 (Tabel 7), hasilnya menunjukkan nilai sig. sebesar $0.050<0.10$, artinya usia berpengaruh pada perubahan sikap terkait pertanian berkelanjutan. Nilai $\operatorname{Exp(B)~sebesar~} 1.345$ menunjukkan bahwa pada usia yang lebih tua peluang meningkatnya sikap (A2) adalah sebesar 1.345 kali dari yang lebih muda usianya. Artinya, peluang peningkatan minat terhadap pertanian berkelanjutan lebih besar pada mereka yang berusia lebih tua dibandingkan generasi muda. Ini menandakan responden yang lebih tua lebih mudah menerima ide-ide terkait kesehatan dibandingkan responden muda. Senada dengan pendapat Soekartawi (1988) bahwa generasi yang lebih tua biasanya bersikap lebih hati-hati, dalam konteks ini adalah terhadap risiko kesehatan yang dikandung pestisida dan pupuk kimia.

\section{Faktor yang mempengaruhi perubahan perilaku dalam perlindungan hutan}

Sementara regresi logistik terhadap P1 (tabel 7) memberikan nilai sig. sebesar $0.083<0.10$ pada variabel bebas luas lahan endline. Artinya luas lahan yang dimiliki seseorang berpengaruh terhadap perubahan perilaku dalam perlindungan hutan (P1). Nilai Exp(B) sebesar 0.104 menunjukkan bahwa jika seseorang memiliki luas tanah $1 \mathrm{Ha}$ lebih luas, maka probabilitas untuk meningkatknya peran dalam pelestarian hutan menurun sebesar 0.104 kali dibanding jika lahannya 1 ha lebih sempit. Hal ini tidak sejalan dengan hasil penelitian Sujarwo (2004) tentang pengaruh luas lahan terhadap pelestarian hutan, tetapi mewakili anggapan setempat bahwa 
orang yang memiliki lahan luas tidak terlibat dalam pelestarian hutan karena lebih sibuk menggarap kebunnya sendiri.

\section{SIMPULAN}

Berdasarkan hasil penelitian yang telah dibahas maka dapat disimpulkan bahwa:

1. Program pemberdayaan masyarakat berpengaruh pada perubahan pengetahuan warga Desa Ambela, Bengel dan Rae Selatan dalam pelestarian hutan dan pertanian berkelanjutan.

2. Program juga berpengaruh terhadap perubahan sikap dan perilaku dalam pertanian berkelanjutan, tetapi tidak berpengaruh terhadap perubahan sikap dan perilaku dalam pelestarian hutan.

3. Program berkontribusi meningkatkan pendapatan anggota kelompok di Desa Ambela, Bengel dan Rae Selatan dalam besaran yang berbeda.

4. Usia, pendidikan, jumlah tanggungan endline dan penghasilan baseline berpengaruh terhadap perubahan pengetahuan tentang keragaman hayati hutan. Sementara itu hanya usia berpengaruh terhadap perubahan sikap dalam pertanian berkelanjutan, dan hanya luas lahan endline yang berpengaruh pada perubahan perilaku dalam pelestarian hutan.

\section{UCAPAN TERIMA KASIH}

Penulis mengucapkan terima kasih kepada warga dan pemerintah Desa Ambela, Bengel dan Rae Selatan yang telah berpartisipasi dalam penelitian ini.

\section{DAFTAR PUSTAKA}

Cameron R. 2015. Mixed Methods Research. Mixed Methods Research Workshop. Perth: Curtin University.

Critical Ecosystem Partnership Fund. 2014. Ecosystem Profile: Wallacea Biodiversity Hotspot. Bogor: Burung Indonesia.

Global Forest Watch. 2018. Interactive Map. [Internet]. [diunduh pada September 2018]. https://www.globalforestwatch.org/map/9/4.10/126.58/ALL/grayscale/loss,forestgain,forest2000?tab= analysis-tab\&geostore $=0$ bdab4732d5643016213c6225d025403\&begin=2001-01-01\&end $=2018-01$ $01 \&$ threshold $=30 \&$ dont_analyze $=$ true.

IDEP. 2016. Kajian Awal Desa Ambela, Bengel dan Rae Selatan. Bali: Yayasan IDEP.

IDEP. 2016. Laporan Narasi Januari - Juni 2016: Program Pemberdayaan Masyarakat dalam Konservasi dan Penghidupan Berkelanjutan di Kabupaten Kepulauan Talaud. Bali: Yayasan IDEP.

IDEP. 2017. CEPF Final Completion Report: Community Empowerment on Conservation and Sustainable Livelihood in Talaud District, North Sulawesi. Bali: Yayasan IDEP.

IDEP. 2017. Laporan Narasi Januari - Juni 2017: Program Pemberdayaan Masyarakat dalam Konservasi dan Penghidupan Berkelanjutan di Kabupaten Kepulauan Talaud. Bali: Yayasan IDEP.

IDEP. 2017. Laporan Narasi Juli - Desember 2016: Program Pemberdayaan Masyarakat dalam Konservasi dan Penghidupan Berkelanjutan di Kabupaten Kepulauan Talaud. Bali: Yayasan IDEP.

Indiahono D. 2016. Crown for Women on Empowerment Program: Studies of Important Position of Women in Poverty Alleviation Program in Banyumas. Sodality: Jurnal Sosiologi Pedesaan. 4(2): 176-182.

Khalik I., Kusmana C., dan Basuni S. 2011. Institutional Analysis to Manage Buffer Zone of Kerinci Seblat National Park: Case Study at Ex-Concession of PT Maju Jaya Raya Timber, North Bengkulu Regency, Bengkulu Province. Jurnal Pengelolaan Sumberdaya Alam dan Lingkungan. 1(1): 1-9.

Kurniawan W., Kusmana C., Basuni S., Munandar A., dan Kholil. 2013. Landuse Conflicts Analysis at Mount Halimun Salak National Park. Jurnal Pengelolaan Sumberdaya Alam dan Lingkungan. 3(1): 23-30.

Pemerintah Indonesia. 2009. Statistik Kehutanan Indonesia 2009. Jakarta: Badan Pusat Statistik.

Pemerintah Indonesia. 2016. Kecamatan Beo Utara Dalam Angka. Melonguane: Badan Pusat Statistik. 
Pemerintah Indonesia. 2017. Kecamatan Beo Dalam Angka. Melonguane: Badan Pusat Statistik.

Pemerintah Indonesia. 2017. Kecamatan Beo Utara Dalam Angka. Melonguane: Badan Pusat Statistik.

Pemerintah Indonesia. 2017. Kecamatan Menlonguane Dalam Angka. Melonguane: Badan Pusat Statistik.

Pemerintah Indonesia. 2017. Statistik Daerah 2017: Kabupaten Kepulauan Talaud. Melonguane: Badan Pusat Statistik.

Saifuddin, Suadi, dan Fadli. 2017. Commodity and Institution Integration; A Model of Rural Economic Empowerment. Sodality: Jurnal Sosiologi Pedesaan. 5(3): 201-209.

Saraswati, Y. dan Darmawan, A.H. 2014. Resiliensi Nafkah Rumahtangga Petani Hutan Rakyat di Kecamatan Giriwoyo, Wonogiri. Sodality: Jurnal Sosiologi Pedesaaan. 2(1): 63-75.

Sarwono SW. 2002. Psikologi Sosial: Individu dan Teori-teori Psikologi Sosial. Jakarta: Balai Pustaka.

Sujarwo. 2004. Pengetahuan, Sikap dan Tindakan Masyarakat Sekitar Hutan dalam Pelestarian Hutan. [tesis]. Bogor: Sekolah Pascasarjana Institut Pertanian Bogor.

Suyodono I, Syaufina L, dan Suharjito D. 2014. An Analysis on Agroforestry Partnership in Order to Minimize Forest Encroachment (Case Study of "Tumpangsari" for Food Crops at Plantation Forest Consession in Pulau Laut, South Kalimantan. Jurnal Pengelolaan Sumberdaya Alam dan Lingkungan. 4(1): 1-8.

Timban JFJ. 2005. Partisipasi Masyarakat dalam Pelestarian Hutan Lindung Gunung Tumpa. [tesis]. Bogor: Sekolah Pascasarjana Institut Pertanian Bogor.

Wahyudi S. 2004. Perilaku Komunikasi Anggota Masyarakat Sekitar Hutan Terhadap Pelestarian Hutan. [tesis]. Bogor: Sekolah Pascasarjana Institut Pertanian Bogor.

Winarto YT. 1999. Dari Paket Teknologi ke Prinsip Ekologi: Perubahan Pengetahuan Petani tentang Pengendalian Hama. Dalam: Petani Merajut Tradisi Era Globalisasi. Bandung: Humaniora Utama Press.

Yusmasari. 2003. Perilaku Komunikasi Masyarakat terhadap Manfaat dan Pelestarian Mangrove di Desa Pematang Pasir, Kecamatan Ketapang, Lampung Selatan. [tesis]. Bogor: Program Pascasarjana Institut Pertanian Bogor. 